\section{A repeat call for complete abandonment of FGM}

\author{
Ian Askew, ${ }^{1}$ Ted Chaiban, ${ }^{2}$ Benoit Kalasa, ${ }^{3}$ Purna Sen ${ }^{4}$
}

The WHO, the Unicef, the United Nations Population Fund (UNFPA) and the United Nations Entity for Gender Equality and the Empowerment of Women (UNWomen) strongly disagree with the opinion of Arora and Jacobs published in the BMJ Journal of Medical Ethics. ${ }^{1}$

In 1997, WHO, Unicef and UNFPA issued a joint statement on female genital mutilation (FGM), which described the public health and human rights implications of the practice and declared support for its abandonment. ${ }^{2}$ This statement was expanded in 2008 with 10 United Nations (UN) agencies signing this updated version. ${ }^{3}$ In 2010, a joint interagency global strategy to end the medicalisation of FGM was released, as it became evident that it was increasingly being performed by healthcare providers. ${ }^{4}$ These interagency statements and strategies reflect consensus among international experts, UN entities and the Member States they represent, and they also articulate agreed language, classification and terminology that are aligned with current evidence. The global commitment to eliminate all forms of FGM by 2030 is clearly stated in target 5.3 of the Sustainable Development Goals (SDG).

FGM is a harmful traditional practice, and given its deep-rooted nature, many communities resist its abandonment for social and cultural reasons, despite the strong evidence of its harms to health and its implications for the full realisation of the rights of girls and women. However, it is alarming when a call to perpetuate the practice, and to encourage healthcare providers to perform FGM, comes from the medical and research community and appears on the pages of a peer-reviewed scientific journal.

There is no medical justification for FGM. Advocating any form of cutting or harm to the genitals of girls and women,

\footnotetext{
${ }^{1}$ Department of Reproductive Health and Research, WHO; ${ }^{2}$ Programme Division, Unicef; ${ }^{3}$ Technical Division, UNFPA; ${ }^{4}$ Policy Division, UNWomen

Correspondence to Dr lan Askew, Department of Reproductive Health and Research, World Health Organization, 20, Ave Appia, 1211 Geneva, Switzerland; askewi@who.int
}

and suggesting that medical personnel should perform it, is unacceptable from a public health and human rights perspective. In 2010, the American Academy of Pediatrics released-and subsequently retracted-a policy statement in which they advocated that paediatricians substitute a 'nicking' procedure for more severe forms of FGM among girls at risk for FGM. The UN and its specialised agencies made the point then and reiterate that all forms of FGM, including what is considered Type IV (pricking, piercing, incising, scraping and cauterisation), are unacceptable, and the implementation of evidencebased comprehensive approaches for the complete abandonment of FGM urgently needs to be accelerated. Condoning and promoting a lesser form of the practice only further tends to normalise, legitimise and perpetuate the harm.

The authors' proposal to advance the practice of FGM by healthcare providers violates the primary principle of the Hippocratic Oath of 'do no harm'. As the commentaries published in response to the Arora and Jacob article note, the argument that this more minor form of FGM may do less harm violates this principle and promotes a practice that causes physical and psychological harm, and perpetuates gender-based discrimination against women and girls. Even if actual harm reduction could be obtained for this generation, the performance of the 'nick' by medical personnel would likely perpetuate the practice through future generations by seeming to legitimise it. It would thus result in greater overall harm. Furthermore, advocating the medicalisation of FGM undermines the decades of work to encourage its abandonment and also minimises the physical and psychological trauma experienced by girls and women who have undergone this practice. As already noted in 2010, the expectation that a 'minor' genital cut will prevent more severe forms of FGM at a later stage is an unproven assumption. Several studies have indicated that many girls are subjected to FGM several times, particularly if the members of the family or of their social network are not satisfied with the result of the first procedure. In addition, there is evidence that what people describe as a 'nick' is often a more severe form of FGM. For example, in a study from Sudan, medical examination revealed that among the women that claimed to have undergone a 'sunna' type of FGM, described as 'just a prick,' about one-third had undergone infibulation, and all had their clitoris and labia minora removed. $^{5}$

FGM represents a form of discrimination against women and girls and is a violation of the rights of children. The practice also violates a person's rights to health, security and physical integrity, the right to be free from torture and cruel, inhuman or degrading treatment, as well as the right to life when the procedure results in death. As evidenced by the SDG target and the many initiatives at the global, national and community level to eliminate the practice of FGM, the international community, including the UN agencies represented here, calls for the complete abandonment of this practice in all its forms and for sustained action to promote the health and rights of girls and women.

\section{Competing interests None declared.}

Provenance and peer review Commissioned; internally peer reviewed.

(c) World Health Organization 2015. Licensee BMJ

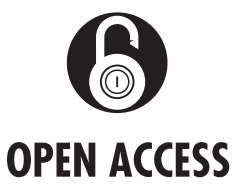

Open Access This is an Open Access article distributed in accordance with the Creative Commons Attribution Non Commercial (CC BY-NC 4.0) license, which permits others to distribute, remix, adapt, build upon this work non-commercially, and license their derivative works on different terms, provided the original work is properly cited and the use is noncommercial. See: http://creativecommons.org/licenses/ by-nc/4.0/

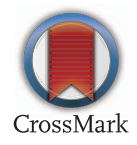

To cite Askew I, Chaiban T, Kalasa B, et al. J Med Ethics 2016:42:619-620.

Accepted 21 March 2016

Published Online First 8 April 2016

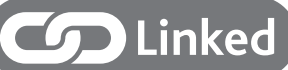

http://dx.doi.org/10.1136/medethics-2014-102375 http://dx.doi.org/10.1136/medethics-2016-103606

$J$ Med Ethics 2016:42:619-620.

doi:10.1136/medethics-2016-103553 


\section{REFERENCES}

1 Arora KS, Jacobs AJ. Female genital alteration: a compromise solution. J Med Ethics 2016;42:148-54.

2 World Health Organization. Female genital mutilation: a joint WHO/UNICEF/UNFPA statement. Geneva: WHO, 1997.
3 World Health Organization. Eliminating female genital mutilation: An interagency statement-OHCHR, UNAIDS, UNDP, UNECA, UNESCO, UNFPA, UNHCR, UNICEF, UNIFEM, WHO. Geneva: WHO, 2008.

4 World Health Organization. Global strategy to stop health-care providers from performing female genital mutilation: UNFPA, UNHCR, UNICEF, UNIFEM, WHO, FIGO, ICN, MWIA, WCPA, WMA. Geneva: WHO, 2010.

5 Elmusharaf S, Elhadi N, Almroth L. Reliability of self reported form of female genital mutilation and WHO classification: cross sectional study. BMJ 2006;333:124. 